\title{
Biochemical characterization of the Arctic char (Salvelinus alpinus) ovarian progestin membrane receptor A Håkan Berg ${ }^{1}$, Peter Thomas ${ }^{1}$ and Per-Erik Olsson*2
}

\author{
Address: ${ }^{1}$ The University of Texas at Austin Marine Science Institute, Port Aransas, Texas, USA and 2Örebro Life Science Center, Department of \\ Natural Sciences, Örebro University, Sweden \\ Email: A Håkan Berg - hberg@utmsi.utexas.edu; Peter Thomas - thomas@utmsi.utexas.edu; Per-Erik Olsson* - per-erik.olsson@nat.oru.se \\ * Corresponding author \\ Published: 10 November 2005 \\ Reproductive Biology and Endocrinology 2005, 3:64 doi:10.1 186//477-7827-3-64 \\ This article is available from: http://www.rbej.com/content/3///64 \\ (c) 2005 Berg et al; licensee BioMed Central Ltd. \\ This is an Open Access article distributed under the terms of the Creative Commons Attribution License (http://creativecommons.org/licenses/by/2.0), \\ which permits unrestricted use, distribution, and reproduction in any medium, provided the original work is properly cited. \\ Received: 05 October 2005 \\ Accepted: 10 November 2005
}

\begin{abstract}
Membrane progestin receptors are involved in oocyte maturation in teleosts. However, the maturation-inducing steroid (MIS) does not appear to be conserved among species and several progestins may fulfill this function. So far, complete biochemical characterization has only been performed on a few species. In the present study we have characterized the membrane progestin receptor in Arctic char (Salvelinus alpinus) and show that the 17,20beta-dihydroxy-4-pregnen-3one $(17,20$ beta-P) receptor also binds several xenobiotics, thus rendering oocyte maturation sensitive to environmental pollutants. We identified a single class of high affinity $\left(\mathrm{K}_{d}, 13.8 \pm 1 . \mathrm{InM}\right)$, low capacity $\left(B_{\max }, 1.6 \pm 0.6 \mathrm{pmol} / \mathrm{g}\right.$ ovary) binding sites by saturation and Scatchard analyses. Receptor binding displayed rapid association and dissociation kinetics typical of steroid membrane receptors, with $\mathrm{t}_{1 / 2} \mathrm{~s}$ of less than I minute. The 17,20 beta-P binding also displayed tissue specificity with high, saturable, and specific 17,20beta-P binding detected in ovaries, heart and gills while no specific binding was observed in muscle, brain or liver. Changes in 17,20beta-P binding during oocyte maturation were consistent with its identity as the oocyte MIS membrane receptor. Incubation of fully-grown ovarian follicles with gonadotropin induced oocyte maturation, which was accompanied by a five-fold increase in 17,20beta-P receptor binding. In addition, competition studies with a variety of steroids revealed that receptor binding is highly specific for 17,20beta-P, the likely maturation-inducing steroid (MIS) in Arctic char. The relative-binding affinities of all the other progestogens and steroids tested were less than $5 \%$ of that of 17,20 beta-P for the receptor. Several ortho, para derivatives of DDT also showed weak binding affinity for the 17,20beta-P receptor supporting the hypothesis that xenobiotics may bind steroid receptors on the oocyte's surface and might thereby interfere with oocyte growth and maturation.
\end{abstract}

\section{Introduction}

Meiosis is arrested at prophase 1 in vertebrate oocytes during their growth phase and a surge in gonadotropin secretion is required to induce the resumption of meiosis and oocyte maturation (OM). It has been demonstrated that gonadotropin (luteinizing hormone, LH) initiates oocyte maturation and ovulation in teleost fish and amphibians by stimulating the production of a maturation inducing substance (MIS) by the ovarian follicles [1]. The MISs have been identified as progesterone in a variety of amphibians and as hydroxylated progestins in teleost fishes [2,3]. Two C21 steroids, 17, 20 $\beta$-dihydroxy-4-pregnen-3-one $(17,20 \beta-P)[4]$ and $17,20 \beta, 21$-trihydroxy-4pregnen-3-one (20ß-S) $[5,6]$, have been positively identi- 
fied as the MISs in amago salmon and Atlantic croaker, respectively. While $17,20 \beta-\mathrm{P}$ is the major MIS for salmonids and cyprinids [2], 20 $\beta-S$ has been shown to be the predominant MIS in sciaenids and some other perciform fishes [3].

MIS does not induce OM in amphibians and teleosts by the classical mechanism of steroid action, instead it acts at the cell surface by binding to receptors located on the oocyte plasma membrane [3,7]. Activation of the MIS receptor results in induction of $\mathrm{OM}$ via a non-genomic mechanism [8] mediated by G-proteins and second messengers such as cAMP $[9,10]$. Progestin membrane receptors (mPRs) have been identified and characterized in several amphibian and teleost species [11-15]. Moreover, membrane progestin receptor ( $\mathrm{mPR}$ ) upregulation by gonadotropins during OM has been demonstrated in several teleost species $[14,16]$ and has been associated with development of the ability of oocytes to become responsive to the MIS (oocyte maturational competence, OMC) and complete OM [17]. A two-stage model of the gonadotropic control of OM in teleosts has been proposed based on the results with several teleost species showing that priming of fully grown follicle-enclosed oocytes by gonadotropin is required to induce OMC [18]. Early studies in rainbow trout (Oncorhynchus mykiss) showing increased $\mathrm{OM}$ in response to the MIS after in vivo treatment with pituitary extracts provided an initial indication that priming with pituitary factors is necessary for the development of OMC in salmonids [19]. However, most studies have been conducted with perciform fishes, so that the mechanisms regulating the development of OMC and its timing relative to other processes during OM remain poorly understood in other teleosts.

The present study describes a comprehensive characterization of the ovarian mPR in a salmonid, Arctic char (Salvelinus alpinus). The Arctic char is of great commercial value in countries in the northern hemisphere, mainly due to its ability to grow at low temperatures, but the species also displays high sensitivity to environmental change. Functional reproduction is of outmost importance for species survival and successful breading in fish farms. Thus it is of great importance to obtain information on the basic mechanisms of reproduction in this species. We demonstrate that the receptor is upregulated during OM. The $\mathrm{mPR}$ abundance increase during OM, suggests its involvement in the development of OMC in salmonid fishes. Furthermore, the receptor display binding to xenobiotics, indicating that it is a target for endocrine disruptors that through binding to the MPR may interfere with oocyte maturation and thereby disrupt reproduction.

\section{Materials and methods Chemicals}

$\left[1,2,6,7-{ }^{3} \mathrm{H}\right] 17 \alpha$-hydroxyprogesterone (specific activity $97 \mathrm{Ci} / \mathrm{mmol}$ ) was obtained from New England Nuclear (Boston, MA) and enzymatically converted to $17,20 \beta-\mathrm{P}$ as described by [20]. The unlabeled steroids were purchased from either Steraloids, Inc. (Wilton, NH) or from Sigma Chemical Company (St. Louis, MO). The xenobiotics o,p'DDT, o,p'-DDE, o,p'-DDD, Kepone and methoxychlor were obtained from Chem Services (Westchester, PA). 4Nonylphenol was obtained from the Huntsman Corporation (Port Neches, TX). Flutamide and cimetidine were purchased from Sigma (St Louis, MO). The antiprogestin ORG31710 was a generous gift of Organon (Oss, The Netherlands) while ZK98,299 and ZK112,993 were generous gifts of Schering AG (Berlin, Germany). All steroids, antihormones and xenobiotics were dissolved in $95 \%$ ethanol to appropriate concentrations and stored at $-20^{\circ} \mathrm{C}$. Chemicals and salts used for making the buffers were purchased from Sigma Chemical Company (St Louis, MO) and from Fisher Scientific (Pittsburgh, PA). The scintillation cocktail was prepared without methanol according to [21].

\section{Animals}

Adult female Arctic char were obtained from Fiskeriverkets Forskningsstation, Kälarne, Sweden and held in indoor tanks with a continuous flow-through water system and fed a commercial Arctic char pelleted diet (Skretting, Norway) daily. A total of 30 fish were used in the present study. Temperature and photoperiod were adjusted to mimic natural conditions during the period of ovarian recrudescence. Fish were maintained under these conditions until their oocytes were fully grown and had diameters of approximately $5 \mathrm{~mm}$.

\section{Tissue sampling and preparation}

Fish were anesthetized with MS222 (Sigma Chemical Company, St Louis, MO), sacrificed, and the ovaries were removed and immediately frozen in liquid nitrogen and stored at $-80^{\circ} \mathrm{C}$ for up to 6 months prior to analysis. Thawed ovarian tissue (1-2 g) was placed between two $700 \mathrm{~nm}$ nylon mesh screens and clamped between two boards to rupture the oocytes and expel the yolk. The yolk was subsequently rinsed from the remaining tissue twice with $20 \mathrm{ml}$ of ice-cold HAEW buffer $(25 \mathrm{mM}$ Hepes, $1 \mathrm{mM}$ $\mathrm{NaCl}, 1 \mathrm{mM}$ EDTA, pH 7.4). The tissue fragments were weighed and placed in $15 \mathrm{ml}(\sim 1: 15 \mathrm{w} / \mathrm{v})$ of ice-cold HAEP buffer (25 mM Hepes, $10 \mathrm{mM}$ dithiothreitol (DTT), $1 \mathrm{mM} \mathrm{NaCl}, 1 \mathrm{mM}$ EDTA, $1 \mathrm{mM}$ PMSF, $\mathrm{pH}$ 7.4) and homogenized using a Polytron (Tekmar Tissuemizer). Homogenization was performed in two steps: first at low speed (setting 4) for 10 seconds and then at moderate speed (setting 7) for 30 seconds. The homogenate was centrifuged at 3,000 $\mathrm{g}$ for 5 minutes to remove the nuclear 
and heavy mitochondrial fractions [22]. The lipid layer was removed from the top and the supernatant was transferred to a new tube. The supernatant was centrifuged at $20,000 \mathrm{~g}$ for 5 minutes to pellet the plasma membrane fraction. The final pellet was resuspended in $10 \mathrm{ml}$ of HAEP buffer and stored at $-80^{\circ} \mathrm{C}$ until analysis.

\section{Receptor Binding Assay}

The filtration assay method originally developed by Patiňo and Thomas [12] to measure the mPR in spotted seatrout ovarian membranes was used with minor modifications. Radiolabeled 17,20ß-P (final concentration 1 $20 \mathrm{nM}$ ) was dissolved in HAEP buffer and a $250 \mu \mathrm{l}$ aliquot was added to each assay tube with or without a 100 -fold excess of cold steroid. The cold steroids were dissolved in ethanol, added to the assay tubes and the ethanol was dried down under $\mathrm{N}_{2}$. To each tube, an aliquot $(250 \mu \mathrm{l})$ of the membrane preparation was added, the tubes were vortexed and incubated for 30 minutes at $+4^{\circ} \mathrm{C}$. The binding reaction was stopped by taking a $250 \mu \mathrm{l}$ aliquot from each tube and passing it through a presoaked glass microfiber filter (Whatman GF/B, $2.1 \mathrm{~cm}$, Whatman, Denmark) on a microfilter holder (Hoefer Scientific Instruments; FH124) attached to a vacuum pump. Each filter was rinsed with $12.5 \mathrm{ml}$ of HAEW buffer and then placed in a $7 \mathrm{ml}$ scintillation vial. Scintillation cocktail $(5 \mathrm{ml})$ was added to each tube, the tubes were shaken for 5 minutes and the radioactivity was measured in a Beckman LS 6000SC scintillation counter (Beckman Instruments, Fullerton, CA). Each sample was assayed in triplicate. Specific binding in each sample was calculated by deducting the non-specific binding from the total binding.

\section{Saturation analysis}

Radiolabeled 17,20ß-P (0.625-30 nM) was added to each reaction tube with or without $3 \mu \mathrm{M}$ cold steroid. Membrane samples were incubated with steroids for $30 \mathrm{~min}$ utes at $+4{ }^{\circ} \mathrm{C}$. The reactions were terminated by filtration and the radioactivity in the filter was determined as described above. Non-linear curve fitting procedures (GraphPad Prism, version 3.03, GraphPad Software Inc) were used to estimate the concentration of $17,20 \beta$-P binding sites $\left(\mathrm{B}_{\max }\right)$ and to calculate the dissociation constant $\left(\mathrm{K}_{\mathrm{d}}\right)$. To determine the time necessary to reach binding equilibrium, membrane preparations were incubated in 7 $\mathrm{nM}$ radiolabeled $17,20 \beta-\mathrm{P}$ with or without $700 \mathrm{nM}$ unlabeled 17,20ß-P. The reaction was terminated at different time-points ranging between 15 seconds to 4 hours. The specific binding for each time-point was determined as described above.

Dissociation kinetics for $\left[{ }^{3} \mathrm{H}\right]-17,20 \beta-\mathrm{P}$ binding to the receptor was determined using standard procedures. Ovarian membrane preparations were first incubated with $7 \mathrm{nM}$ radiolabeled $17,20 \beta-\mathrm{P}$ in the absence (total bind- ing) or presence (nonspecific binding) of $700 \mathrm{nM}$ unlabeled 17,20 $\beta$-P for 30 minutes to ensure maximum association of the radioligand to the receptor. Aliquots $(500 \mu \mathrm{l})$ of the membrane receptor suspensions were subsequently added to tubes containing $700 \mathrm{nM}$ unlabeled $17,20 \beta$-P $(500 \mu \mathrm{l})$ and incubated at $+4^{\circ} \mathrm{C}$. At various time points ranging between 15 seconds and 4 hours the reactions were terminated and the specific binding for each time point was determined as described above.

\section{Tissue specificity}

Plasma membrane suspensions were made from ovaries, heart, gill and muscle tissue as described above. All samples were assayed in triplicate and the resuspended membrane preparations were incubated with $7 \mathrm{nM}$ of radiolabeled $17,20 \beta-\mathrm{P}$ in the presence or absence of 700 $\mathrm{nM}$ unlabeled steroid. After 30 minutes incubation at $+4^{\circ} \mathrm{C}$ the reaction was terminated by filtration and the specific binding for each membrane preparation was determined as described above.

\section{Steroid specificity}

The steroid specificity of receptor binding was examined using a competitive binding assay. Ovarian tissue membrane preparations were incubated for 30 minutes in tubes containing $7 \mathrm{nM}\left[{ }^{3} \mathrm{H}\right]-17,20 \beta-\mathrm{P}$ with or without 11 different steroids at concentrations ranging between 0.1 $\mathrm{nM}$ and $10 \mu \mathrm{M}$. The following steroids were tested:

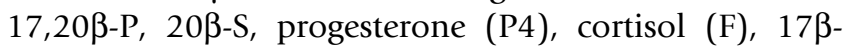
estradiol (E2), 11-ketotestosterone (11-KT), testosterone (T), 11-deoxycorticosterone (11-DOC), 17 $\alpha$-hydroxyprogesterone (17 $\alpha-\mathrm{OH}-\mathrm{P}), 11$-deoxycortisol (DC), and pregnenolone (P5). All cold steroids were dissolved in ethanol and added to the assay tubes. The ethanol was subsequently dried down under $\mathrm{N}_{2}$. After 30 minutes incubation at $+4^{\circ} \mathrm{C}$ the reaction was terminated by filtration and the specific binding was determined as described above.

\section{Effects of in vitro gonadotropin treatment on 17,20 $\beta-P$ binding to ovarian $m P R$}

The possible hormonal regulation of ovarian 17,20 -P receptor by gonadotropin was investigated in vitro. Freshly prepared ovarian fragments $(3 \mathrm{~g})$ were incubated in Dulbecco's Modified Eagle's medium with Ham's nutrient mixture F-12 (DME/F12) (30 ml) containing 1, 7 and 14 IU human chorionic gonadotropin (hCG)/ml. The fragments were incubated at $+15^{\circ} \mathrm{C}$ for 20 hours under an atmosphere of oxygen. At the end of the incubation the medium was discarded and the tissue fragments stored at $-80^{\circ} \mathrm{C}$ until assayed for $17,20 \beta-\mathrm{P}$ binding.

To investigate the time course of $17,20 \beta-\mathrm{P}$ receptor regulation by hCG, ovarian fragments $(3 \mathrm{~g})$ were incubated for time-points ranging between 0 and 20 hours in DME/F12 containing $14 \mathrm{IU} \mathrm{hCG} / \mathrm{ml}$. At the end of each incubation 

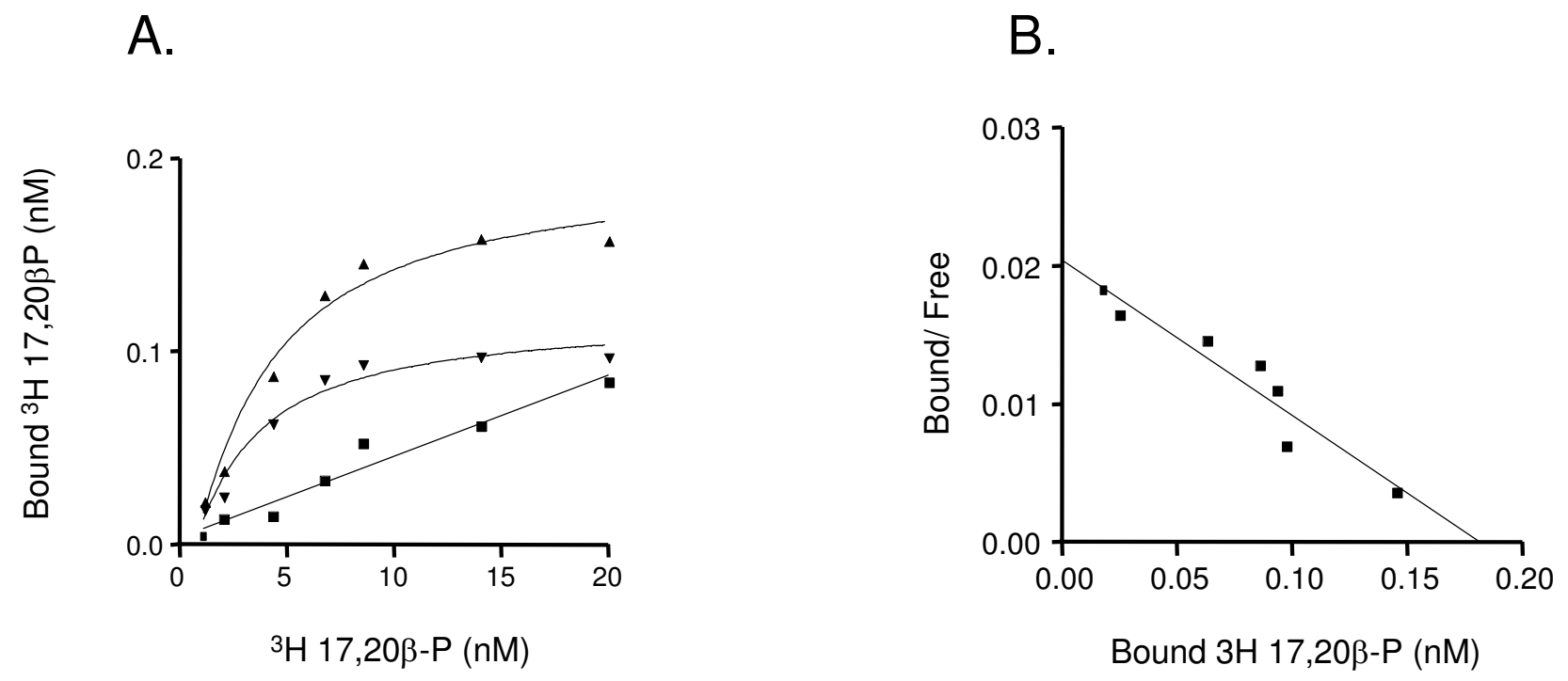

\section{Figure I}

Representative saturation curve (A) and Scatchard analysis (B). Specific binding of $\left[{ }^{3} \mathrm{H}\right]-\mathrm{I}$, 20 $3-\mathrm{P}$ to the plasma membrane fraction of Arctic char ovaries using membrane suspensions incubated with $\left[{ }^{3} \mathrm{H}\right]-17,20 \beta-\mathrm{P}$ at concentrations ranging between I nM- 20 nM with or without a 100 fold excess non radiolabeled I7,20 -P. Specific binding ( $\nabla)$ was determined by subtracting non-specific binding $(\mathbf{\square})$ from total binding $(\mathbf{A})$. TB: total binding, NSB: nonspecific binding, SB: specific binding. All points are means of triplicate determinations.

the ovarian fragments were removed from the medium, some of the oocytes were examined for germinal vesicle migration (GVM) and germinal vesicle breakdown (GVBD), and the remaining ovarian tissue was immediately stored at $-80^{\circ} \mathrm{C}$ until analysis. Estimations of $17,20 \beta$-P binding were obtained as described above.

\section{Interactions of xenobiotics and hormone antagonists with the $\mathrm{mPR}$}

The binding affinities of a variety of xenobiotic chemicals for the $17,20 \beta-P$ membrane receptor were investigated to determine whether the 17,20ß-P action mediated by this receptor was potentially susceptible to chemical disruption. The xenoestrogens nonylphenol, Kepone, and o,p'DDT with its metabolites o,p'-DDE and o,p'-DDD, the androgen antagonist flutamide, the progestin antagonists ZK 98299, ZK112992 and ORG 31710 and the H2 histamine receptor antagonist cimetidine were tested for receptor binding. All xenobiotics were added to the assay tubes dissolved in ethanol, which was dried down under $\mathrm{N}_{2}$ prior to addition of tissue preparation. The ovarian tissue suspensions were prepared as described above and incubated with $7 \mathrm{nM}\left[{ }^{3} \mathrm{H}\right]-17,20 \beta-\mathrm{P}$ in absence or presence of the xenobiotics over a broad range of concentrations $(0,1$ $\mathrm{nM}-1 \mathrm{mM}$ ). After a 30 minutes incubation at $+4^{\circ} \mathrm{C}$ free steroid was removed by filtration. The specific binding for each tissue suspension was determined as described above. The binding of xenobiotics to the 17,20ß-P receptor was expressed as a percentage of the maximum specific binding of 17,20ß-P binding to its receptor.

\section{Data analysis}

The significance $(\mathrm{P})$ was calculated using a one way ANOVA followed by Bonferroni's multiple comparison test with a $\mathrm{P}<0.05$. All statistical analysis was performed using GraphPad Prism version 3.03 for Windows (GraphPad Software, San Diego California USA).

\section{Results}

Receptor characterization

High affinity (Kd, $13.8 \pm 1.1 \mathrm{nM})$, specific $17,20 \beta$-P binding sites were detected on Arctic char ovarian plasma membranes by saturation analysis. Receptor binding was saturated at a concentration of $7 \mathrm{nM} 17,20 \beta-\mathrm{P}$ and Scatchard analysis showed a single class of limited capacity (Bmax, $1.6 \pm 0.6 \mathrm{pmol} / \mathrm{mg}$ ovary) binding sites for 17,20ß-P (Fig. 1). Specific binding was detected over the $\mathrm{pH}$ range of 7.0 to 7.8 with maximum receptor binding at pH 7.4 (data not shown).

The association kinetics of $17,20 \beta$-P binding to the receptor was rapid and saturation of the binding sites was achieved after 3 minutes at $+4^{\circ} \mathrm{C}$, with a $\mathrm{t}_{1 / 2}$ of $42 \pm 3.4$ seconds (Fig. 2). The non-specific binding did not change 


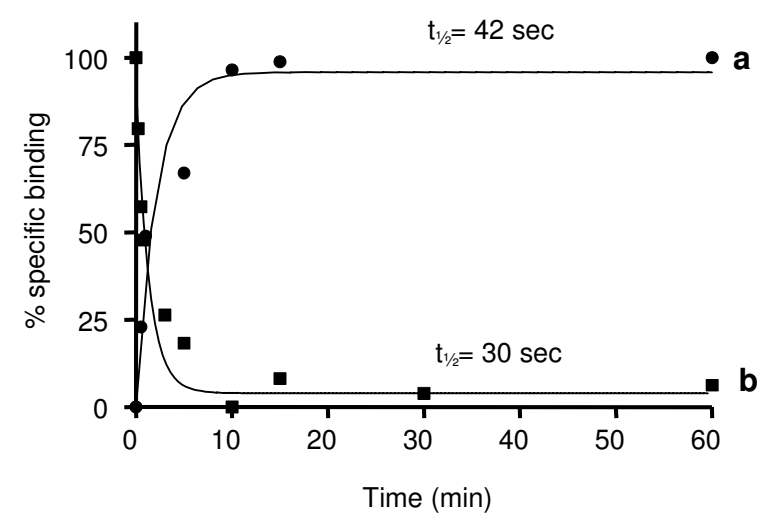

Figure 2

Association (O) and dissociation ( $\square$ ) kinetics. $\left[{ }^{3} \mathrm{H}\right]$ 17,20 $\beta-P$ binding to Arctic char ovarian plasma membrane preparations. The reactions were terminated at time-points ranging between 15 seconds and 4 hours. The data are expressed as percentages of maximum specific binding. Each point represents the average of three replicate assays.

throughout the incubation time. The binding of $\left[{ }^{3} \mathrm{H}\right]-$ $17,20 \beta-\mathrm{P}$ to the receptor was readily displaced with unlabeled 17,20ß-P. The kinetics of dissociation were rapid and $\left[{ }^{3} \mathrm{H}\right]-17,20 \beta-\mathrm{P}$ was completely dissociated from the receptor after 5 minutes of incubation at $+4^{\circ} \mathrm{C}$, with a $\mathrm{t}_{1 / 2}$ of $30 \pm 4.2$ seconds (Fig. 2).

Specific $17,20 \beta$-P binding was detected in membrane fractions of ovary, heart and gill Arctic char tissues, whereas no binding was detected in muscle tissue (Fig. 3). Highest $17,20 \beta-P$ receptor binding was measured in ovarian tissue. High amounts of $17,20 \beta-\mathrm{P}$ binding were also observed in brain and liver tissues but subsequent saturation and Scatchard analyses showed that these binding moieties did not have the binding characteristics of steroid receptors (data not shown). In vitro treatment of ovarian fragments with gonadotropin (hCG) for 20 hours caused a concentration-dependent increase in 17,20ß-P binding to the mPR. Maximum induction of the mPR, a five-fold increase over initial levels, was observed following treatment with $14 \mathrm{IU}$ hCG/ml (Fig. 4). The time course study revealed that $17,20 \beta-\mathrm{P}$ binding to the $\mathrm{mPR}$ increased after 6-8 h of hCG treatment (Fig. 5), but that the increase was not significant until 12 hours of hCG treatment. Maximum receptor binding was not observed until after 20 hours of hCG exposure. These changes in $\mathrm{mPR}$ binding were accompanied by the induction of maturation of the follicle-enclosed oocytes. GVM, an early stage of OM, was first observed in about $10 \%$ of the oocytes after 6 hours of hCG incubation (Fig. 5). The proportion of oocytes undergoing GVM reached a maximum of $75 \%$ after 12 hours and subsequently declined at 20

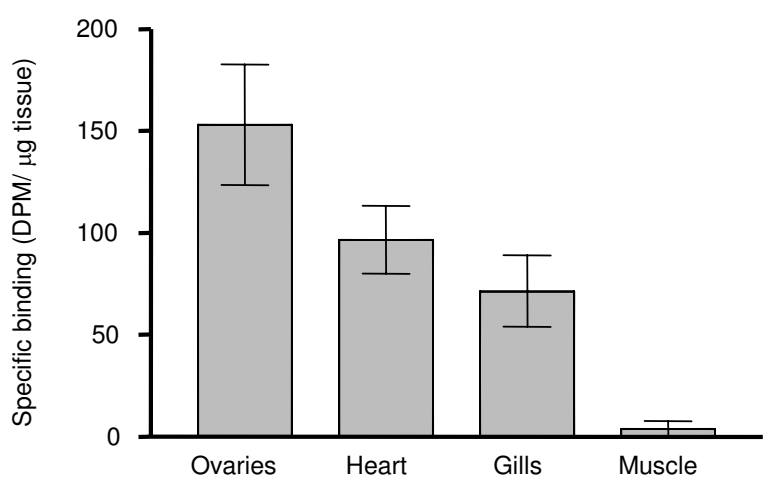

Figure 3

Relative receptor abundance in different tissues. Specific $\left[{ }^{3} \mathrm{H}\right]-17,20 \beta-P$ binding to membrane preparations of Arctic char ovary, heart, gill and muscle tissues. Data are presented as means \pm SEM, obtained from three females.

hours as the oocytes proceeded to the later GVBD stage of OM.

Competition studies showed that steroid binding to the Arctic char ovarian membrane fraction was specific for C21 $\Delta 4$ (4-ene) steroids lacking a functional group at the 11 position, cortisol and pregnenolone displaying negligible affinity for the receptor (Fig. $6 \mathrm{a}, \mathrm{c}$ ). The common fish androgens (C19 steroids) T and 11-KT also showed little or no affinity for the receptor (Fig. 6b). The C18 steroid E2 displayed the highest relative binding affinity (5\%) to the receptor of the other major steroids present in fish plasma

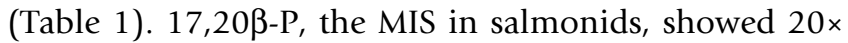
higher binding affinity for the receptor than any of the other steroids or xenobiotics tested. Removal of the $\mathrm{OH}$ group at the 20 position of the side chain of $17,20 \beta-P$, resulting in the formation of $17 \alpha \mathrm{OH}-\mathrm{P}$, resulted in a fortyfold decrease in the relative binding activity (RBA) which was not further altered by the additional removal of the $\mathrm{OH}$ group on the 17 position (P4). Addition of an $\mathrm{OH}$ group at the 21 position of $17,20 \beta-P$, to produce $20 \beta-S$, the other major fish MIS, caused an 80 fold decline in binding affinity. Other 11-deoxycorticosteroids (11-DOC, DC) had similar RBAs as $20 \beta-S$. The presence of a functional $(\mathrm{OH})$ group at the 11 position of a C21 steroid, cortisol (F), resulted in a further loss of binding affinity. Finally alterations of the ketone at the 3 position of progesterone to a hydroxyl and repositioning of the double bond to the 5 position ( $\mathrm{P} 5, \Delta 5$, 5-ene steroid) resulted in a complete loss of binding affinity.

All synthetic hormone antagonists and xenobiotics tested showed low or no binding affinity for the 17,20 $\beta$-P receptor (Table 1; Fig. 6d). The highest binding affinity was dis- 


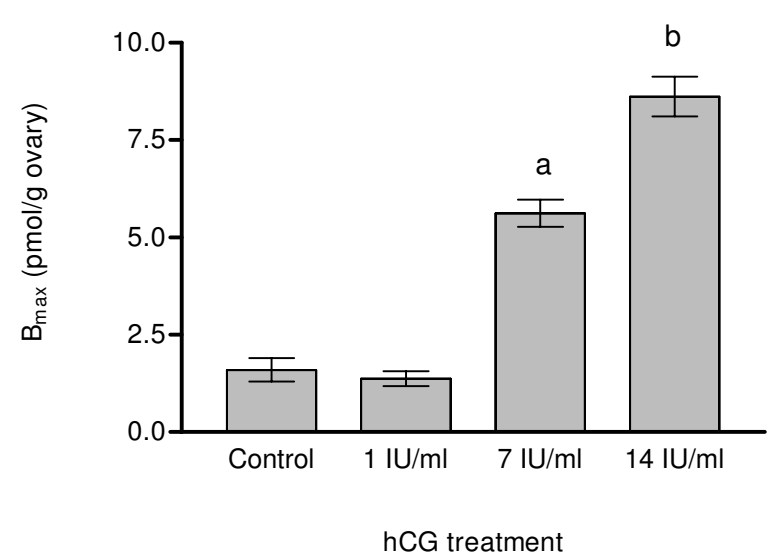

Figure 4

Concentration-dependent effects of in vitro gonadotropin (hCG) treatment on ovarian I 7,20 $\beta$-P binding to $\mathbf{M P R}$. Ovarian fragments were incubated with $0,1,7$, or I 4 IU hCG for 20 hours. Each bar represents the mean \pm SEM of triplicate determinations. Significant difference at the $\mathrm{P}<0.0$ I level compared to control (a) and the 7 IU group (b) are indicated in the figure.

played by the androgen antagonist flutamide, which had a RBA of $0.49 \%$, a $50 \times$ higher affinity than $\mathrm{T}$, the strongest binding androgen. The progestin antagonist ZK112992 also showed weak binding affinity $(0.11 \%)$ for the mPR. Among the xenobiotics tested o,p'-DDT and its metabolite $\mathrm{o}, \mathrm{p}^{\prime}$-DDD had a RBA less than $1 \%$ that of the natural ligand, $17,20 \beta-P(0.37 \%$ and $0.30 \%$ respectively), while the other DDT metabolite o,p'-DDE, Kepone and nonylphenol did not bind the 17,20 $\beta$-P receptor.

\section{Discussion}

In the present study, a 17,20 $\beta$-P binding moiety was identified in Arctic char ovarian plasma membranes that fulfil all the criteria for its designation as a steroid membrane receptor. A single class of high affinity $\left(\mathrm{K}_{\mathrm{d}}, 13.8 \pm 1.13\right.$ $\mathrm{nM}, \mathrm{N}=6)$, saturable $\left(\mathrm{B}_{\max }, 1.6 \pm 0.6 \mathrm{pmol} / \mathrm{g}\right.$ ovary $)$ and displaceable, specific 17,20 $\beta$-P binding sites are detectable on ovarian membranes. The kinetics of $17,20 \beta$-P association and dissociation to the membrane binding sites are very rapid, with $t_{1 / 2} s$ less then a minute, which is typical of steroid membrane receptors. The binding is highly specific for $17,20 \beta-\mathrm{P}$ and other progestins and is negligible for other steroids. The binding also shows tissue specificity, with highest levels of specific binding in the ovaries, a known target of $17,20 \beta-\mathrm{P}$ action. It was also found that $17,20 \beta$-P binding to mPR in Arctic char ovaries increase dramatically during OM which supports the suggestion that gonadotropin-induced upregulation of the

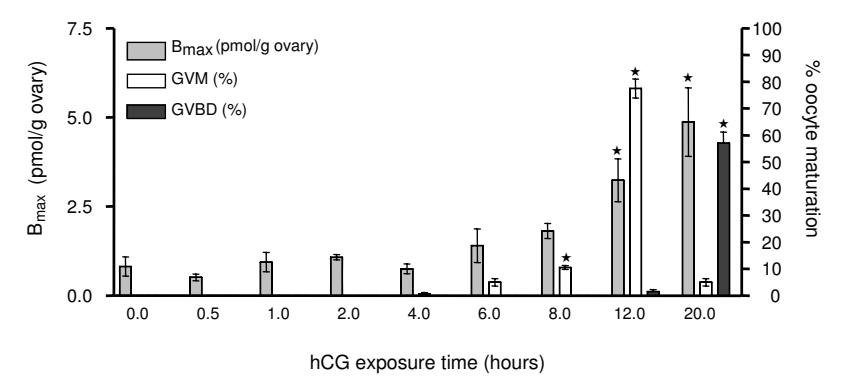

Figure 5

Time course of increased ovarian I7,20 $\beta$-P binding to MPR and oocyte maturation. Arctic char ovarian fragments were incubated with I $4 \mathrm{IU} \mathrm{hCG} / \mathrm{ml}$. At the end of each incubation period, oocytes were examined for 17,20 $\beta-P$ binding and the occurrence of GVM and GVBD. Each bar represents the mean \pm SEM from 5 different fishes, each one assayed in triplicate. $* P<0.01$ compared to other time points.

MIS receptor is a common occurrence amongst teleosts and is of physiological importance during OM [17].

Specific binding of the salmonid MIS, 17,20 $\beta$-P, and the synthetic progestin R5020 has been demonstrated with ovarian and oocyte plasma membranes from brook trout (Salvelinus fontinalis) [23] and rainbow trout [13]. Overall, the binding characteristics of the Arctic char ovarian mPR are similar to those reported previously. The affinity of $17,20 \beta$-P binding $\left(\mathrm{K}_{\mathrm{d}}, 13.8 \mathrm{nM}\right.$, to the mPR on Arctic char ovaries is similar to that reported for MIS binding to the $\mathrm{mPR}$ in rainbow trout (Oncorhynchus mykiss, $\mathrm{K}_{\mathrm{d}}-18 \mathrm{nM}$ ) and yellowtail (Seriola quinqueradiata $\mathrm{K}_{\mathrm{d}}, 22.9 \mathrm{nM}$ ), but somewhat lower than that reported in spotted seatrout (Cynoscion nebulosus, ovaries: $\mathrm{K}_{\mathrm{d}}, 1.5-6.0 \mathrm{nM}$ ) and striped bass (Morone saxatilis $\mathrm{K}_{\mathrm{d}}, 1.4 \mathrm{nM}$ ) gonadal membrane fractions [12-15]. The slightly higher $\mathrm{K}_{\mathrm{d}} \mathrm{s}$ in rainbow trout tissues could be related to the higher amounts of MIS present in the plasma of this species [24] compared with Arctic char [25], while the lower $K_{d}$ found in spotted seatrout and striped bass correlates well with lower MIS plasma levels during OM in these species $[17,26]$.

The Arctic char ovarian MPR has a limited binding capacity for $17,20 \beta-P(1.6 \pm 0.6 \mathrm{pmol} / \mathrm{g}$ ovary $)$, similar to the $17,20 \beta$-P receptor binding capacity reported previously in yellowtail (2.1 pmol/g ovary; [15]). The membrane receptor demonstrated rapid association and dissociation kinetics to the ligand as well as high ligand and tissue specificity, all specific characteristics of a steroid membrane receptor. The association and dissociation rates $\left(\mathrm{T}_{1 / 2}<1\right.$ minute, equilibrium reached within 3 minutes) were similar to previously reported ovarian membrane receptor binding for MIS in some sciaenids [12], but differs from 
Table I: EC 50 and relative binding affinity (RBA) of various steroids and xenobiotics for Arctic char ovarian membrane fractions.

\begin{tabular}{|c|c|c|}
\hline Competitor & Concentration (nM) causing $\mathbf{5 0 \%}$ displacement & RBA (\%) \\
\hline 17,20ß-P & 1.25 & 100.0 \\
\hline E2 & 37.9 & 4.68 \\
\hline P4 & 52.6 & 3.37 \\
\hline $17 \alpha-\mathrm{OH}-\mathrm{P}$ & 69.3 & 2.56 \\
\hline II-DOC & 132.3 & 1.34 \\
\hline $20 \beta-S$ & 145.2 & 1.22 \\
\hline DC & 207.1 & 0.86 \\
\hline Flutamide & 256.1 & 0.49 \\
\hline o,p'-DDT & 377.5 & 0.37 \\
\hline $0, p^{\prime}-D D D$ & 549.2 & 0.30 \\
\hline ZK II 2992 & 1179 & 0.11 \\
\hline ZK 98299 & 12879.8 & 0.01 \\
\hline $\mathrm{F}$ & |442|.2 & 0.01 \\
\hline $\mathrm{T}$ & $|8347.2|$ & 0.01 \\
\hline $\mathrm{II}-\mathrm{KT}$ & ND & 0.0 \\
\hline P5 & ND & 0.0 \\
\hline Kepone & ND & 0.0 \\
\hline Nonylphenol & ND & 0.0 \\
\hline o,p'-DDE & ND & 0.0 \\
\hline Cimetidine & ND & 0.0 \\
\hline ORG 31710 & ND & 0.0 \\
\hline
\end{tabular}

ND indicates substances that did not display $50 \%$ displacement of $17,20 \beta-P$ from its receptor in the range of concentrations examined (steroids: 0.1 $\mathrm{nM}-10 \mu \mathrm{M}, \mathrm{RBA}<0.01 \%$; xenobiotics, hormone antagonists: $0.1 \mathrm{nM}-\mathrm{I} \mathrm{mM}, \mathrm{RBA}<0.0001 \%)$.

the reported $t_{1 / 2}$ from carangids [15] where the $t_{1 / 2} s$ were found to be slower (15 minutes).

An interesting finding was that gonadotropin induction of $\mathrm{OM}$ in vitro was associated with a dramatic five-fold increase in mPR concentrations in Arctic char ovarian tissues. Upregulation of $\mathrm{mPR}$ concentrations by gonadotropin during induction of $\mathrm{OM}$ in vitro has been observed previously in spotted seatrout ovaries $[17,27]$. It has been suggested that exposure to gonadotropin is necessary for the development of oocyte maturational competence and the onset of OM [28]. The Arctic char 17,20 $\beta$-P membrane receptor displayed dose-dependent induction when preincubated in hCG for 20 hours. A time-course experiment showed that $17,20 \beta$-P binding activity was significantly increased after 12 hours treatment with hCG. The timing of the MPR upregulation was associated with GVM and the onset of GVBD after gonadotropin treatment. GVM occurred in a high percentage of the oocytes after 12 hours, and GVBD was observed between 12 and 20 hours of hCG treatment of whole Arctic char ovary fragments. These results are consistent with a physiological role for increased 17,20ß-P binding to the mPR on the oocyte surface during oocyte maturation.

Determination of steroid specificity showed that $17,20 \beta$ $P$ had the highest binding affinity, followed by E2 $(4.68 \%)$ while 11 -DOC and $20 \beta$-S only had RBAs of
$1.34 \%$ and $1.22 \%$, respectively. These RBAs are comparable to results obtained with the yellowtail $\mathrm{MPR}$, where $17,20 \beta-P$ is the ligand with highest affinity [15]. In yellowtail the receptor binding-affinity for 11-DOC was slightly higher $(3.2 \%)$ and $20 \beta-S$ was slightly lower $(0.8 \%)$ than observed for Arctic char.

It has been found that xenobiotic chemicals can interfere with nongenomic, cell surface-mediated actions of steroids $[29,30]$. Low, environmentally realistic, concentrations of a variety of xenobiotics has been shown to impair OM in vitro in response to the MIS in spotted seatrout and Atlantic croaker ovarian fragments [29,31], and also antagonize MIS upregulation of sperm motility [32]. The observation that these compounds could bind to the mPR on seatrout oocytes and croaker sperm provided the first indication that chemicals could interfere with nongenomic steroid actions by a receptor-mediated mechanism. Xenobiotic chemical binding to $\mathrm{mPR}$ was confirmed in a salmonid species for several of these compounds in the present study. In Arctic char both o,p'DDT and o,p'DDD showed significant binding to the mPR, with RBAs of $0.37 \pm 0.04 \%$ and $0.30 \pm 0.04 \%$ respectively. However, Kepone and the other xenobiotics tested did not show measurable binding to the membrane 17,20ß-P receptor at concentrations up to $1 \mathrm{mM}$. In contrast, Kepone displayed the highest binding affinity of the chemicals tested for the spotted seatrout mPR (RBA 
A

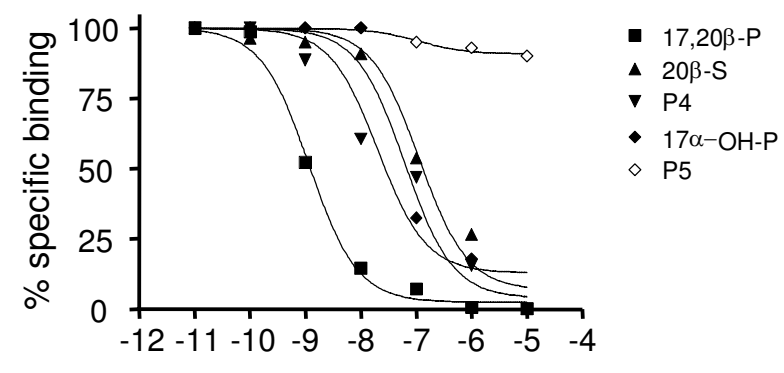

$\log$ Competitor concentration (M)

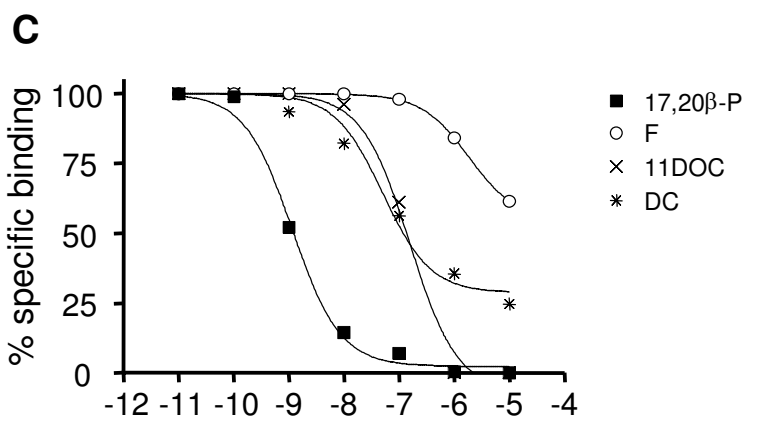

log Competitor concentration (M)
B

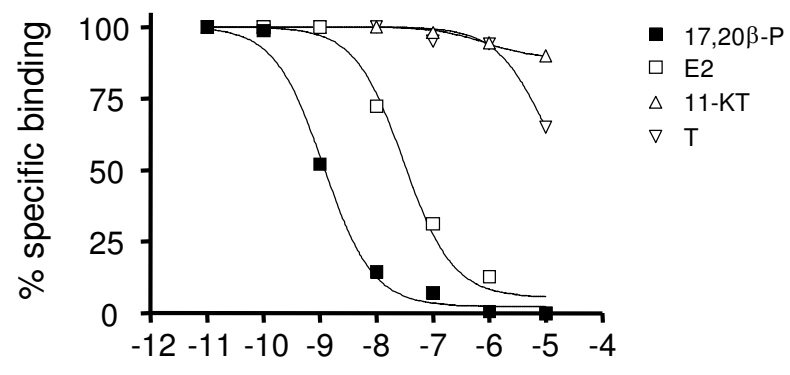

log Competitor concentration (M)

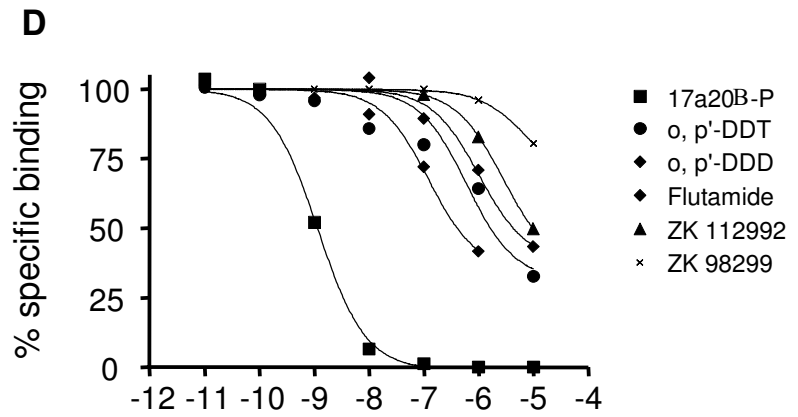

log Competitor concentration (M)

\section{Figure 6}

Competition by various steroids for binding of $\left[{ }^{3} \mathrm{H}\right] 1$ 17,20 $3-\mathrm{P}$ to ovarian plasma membranes. Ovarian membrane preparations were incubated for 30 minutes with $\left[{ }^{3} \mathrm{H}\right]-17,20 \beta-\mathrm{P}$ in the presence of $10 \mathrm{pM}-10 \mu \mathrm{M}$ competitor. For explanation of abbreviations see Materials and Methods. Each point represents the mean of triplicate determinations. A) progestogens. B) androgens and estrogen. C) corticosteroids. D) xenobiotics.

$0.1 \%$ relative to $20 \beta-S$ ), followed by o,p'DDD, methoxychlor and o,p'-DDT which showed weak displacement of $20 \beta$-S binding [29]. These differences in the binding affinities of xenobiotics for the spotted seatrout and Arctic char mPRs are not surprising, since these receptors also display marked differences in their RBAs for steroids. The spotted seatrout mPR shows the highest binding affinity for $20 \beta$ $S$ and $17,20 \beta$-P has a RBA of $0.64 \%$ [32], while Arctic char $\mathrm{mPR}$ shows highest binding affinity for $17,20 \beta-\mathrm{P}$ and $20 \beta$ $S$ has a RBA of $1.2 \%$. These results indicate that the mPR located on Arctic char ovarian plasma membranes is a possible target for endocrine disruption. However, further research is needed to determine the extent of xenobiotic interactions with mPRs and their effects on reproduction.

In conclusion, this study shows the presence of a highly specific $17,20 \beta-\mathrm{P}$ receptor located in the ovarian plasma membrane in Arctic char. The receptor was identified as a high affinity and a low capacity mPR. This study also sug- gests that abundance of the Arctic char mPR has biological relevance since both the receptor density on the oocyte surface and the onset of OM clearly are regulated by gonadotropin. Furthermore, the interaction of xenobiotics with $\mathrm{MPR}$ suggests that it may be a target for endocrine disruption resulting in reduced OM thereby reducing the reproductive success.

\section{Acknowledgements}

This research was partially supported by Environmental Protection Agency STAR Grant R-8290240 I (to P.T.), the Swedish Foundation for International Cooperation in Research and Higher Education (STINT) (to A.H.B.), Knut and Alice Wallenberg Foundation (to A.H.B.), the Swedish Environmental Protection Agency (to P.-E.O.), the Swedish Animal Welfare Agency (to P.-E.O.) and the Swedish Knowledge Foundation (to P.-E.O.).

\section{References}

I. Nagahama Y: Endocrine control of oocyte maturation. In Hormone and Reproduction in Fishes Amphibians and Reptiles Edited by: Norris DO, Jones RE. New York:PlenumPress; 1987:I7I-202. 
2. Scott AP, Canario AVM: Status of oocyte maturation-inducing steroids in teleosts. Proc Third Int Symp Reprod Physiol Fish 1987:223-234.

3. Thomas P: Hormonal control of oocyte maturation in sciaenid fishes. In Perspectives in Comparative Endocrinology Edited by: Davey KG, Peter RE, Tobe SS. Nat Res Council of Canada, Ottawa; 1994:619-625.

4. Nagahama $Y$, Adachi S: Identification of maturation-inducing steroid in a teleost, the amago salmon (Oncorhynchus rhodurus). Dev Biol 1985, 109:428-435.

5. Trant JM, Thomas P, Shackleton CHL: Identification of 17-alpha20-beta 2 I trihydroxy-4-pregnen-3-one as the major ovarian steroid produced by the teleost Micropogonias undulatus during final oocyte maturation. Steroids 1986, 47:89-100.

6. Trant J, Thomas P: Isolation of a novel maturation-inducing steroid produced in vitro by ovaries of Atlantic croaker. Gen Comp Endocrinol 1989, 75:397-404.

7. Liu Z, Patiño R: High-affinity binding of progesterone to the plasma membrane of Xenopus oocytes: Characteristics of binding and hormonal and developmental control. Biol Reprod 1993, 49:980-988.

8. Nagahama Y, Yoshikuni M, Yamashita M, Yokumoto T, Katsu Y: Regulation of oocyte growth and maturation in fish. Curr Top Dev Biol 1995, 30: 103-145.

9. Yoshikuni M, Nagahama Y: Involvement of an inhibitory G-protein in the signal transduction pathway of maturation-inducing hormone (17 $\alpha, 20 \beta$-dihydroxy-4-pregnen-3-one) action in rainbow trout (Oncorhynchus mykiss) oocytes. Dev Biol 1994, 166:615-622.

10. Thomas P, Zhu Y, Pace M: Progestin membrane receptors involved in the meiotic maturation of teleost oocytes: a review with some new findings. Steroids 2002, 67:5 II-5I7.

II. Sadler SE, Maller JL: Identification of a steroid receptor on the surface of Xenopus oocytes by photoafinity labeling. J Biol Chem 1982, 257:355-36I.

12. Patiño R, Thomas P: Characterisation of a membrane receptor activity for $17 \alpha, 20 \beta, 21$-trihydroxy-4-pregenen-3-one in ovaries of spotted seatrout (Cynoscion nebulosus). Gen Comp Endocrinol 1990, 78:204-217.

13. Yoshikuni M, Shibata N, Nagahama $Y$ : Specific binding of $\left[{ }^{3} \mathrm{H}\right] 17 \alpha, 20 \beta$-dihydroxy-4-pregnen-3-one to oocyte cortices of rainbow trout. Fish Physiol Biochem 1993, I I:I5-24.

14. King W, Ghosh S, Thomas P, Sullivan CV: A receptor for the oocyte maturation-inducing hormone $17 \alpha, 20 \beta, 21$-trihydroxy-4-pregnen-3-one on ovarian membranes of striped bass. Biol Reprod 1997, 56:266-27I.

15. Rahman M, Ohta K, Yoshikuni M, Nagahama Y, Chuda H, Matsuyama M: Characterization of ovarian membrane receptor for 17,20beta-dihydroxy-4-pregnen-3-one, a maturation-inducing hormone in yellowtail, Seriola quinqueradiata. Gen Comp Endocrinol 2002, I 27:7|-79.

16. Thomas P, Patiño R: Changes in 17 $\alpha, 20 \beta, 21$-trihydroxy-4-pregnen-3-one membrane receptor concentrations in ovaries of spotted seatrout during final oocyte maturation. Proc Fourth Int Symp Reprod Physiol Fish 1991:122-124.

17. Thomas $P$, Pinter J, Das S: Upregulation of the maturationinducing steroid membrane receptor in spotted seatrout ovaries by gonadotropin during oocyte maturation and its physiological significance. Biol Reprod 200I, 64:2I-29.

18. Patiño R, Yoshozaki G, Thomas P, Kagawa H: Gonadotropic control of ovarian follicle maturation: the two-stage concept and its mechanism. Comp Biochem Physiol B 200I, I 29:427-439.

19. Jalabert $B$, Breton $B$, Fostier $A$ : Precocious induction of oocyte maturation and ovulation in rainbow trout (Salmo gairdneri): problems when using 17 $\alpha, 20 \beta$-dihydroprogesterone. Annu Biol Anim Biochem Biophys 1978, I 8:977-984.

20. Scott AP, Sheldrick EL, Flint AP: Measurement of 17 alpha, 20 beta-dihydroxy-4-pregnen-3-one in plasma of trout (Salmo gairdneri Richardson): seasonal changes and response to salmon pituitary extract. Gen Comp Endocrinol 1982 , 46(4):444-45।.

21. Pinter J, Thomas P: Characterisation of a progestogen receptor in the ovaries of the spotted seatrout, Cynoscion nebulosus. Biol Reprod 1995, 52:667-675.

22. Graham JM: Isolation of mitochondria, mitochondrial membranes, lysosomes, peroxisomes, and Golgi membranes from rat liver. In Biomembrane Protocols. I isolation and analysis Edited by: Graham J, Higgins J. Totowa, NJ: Human Press; 1993:29-40.

23. Maneckjee A, Idler DR, Weisbart M: Demonstration of putative membrane and cytosol steroid receptors for $17 \alpha, 20 \beta$-dihydroxy-4-pregnene-3-one in brook trout Salvelinus fontinalis oocytes by photoaffinity labeling using synthetic progestins |7,2I-dimethyl-19-nor-pregn-4,9-diene-3.20-dione (R5020). Fish Physiol Biochem 1991, 9:123-135.

24. Scott AP, Sumpter JP: A comparison of the female reproductive cycles of autumn-spawning and winter-spawning strains of rainbow trout (Salmo gairdneri Richardson). Gen Comp Endocrinol 1983, 52:79-85.

25. Mayer I, Schmitz M, Borg B, Schultz R: Seasonal endocrine changes in male and female Arctic charr (Salvelinus alpinus). I. Plasma levels of three androgens, 17 $\alpha$-hydroxy-20 $\beta$-dihydroprogesterone, and $17 \beta$-estradiol. Canadian Journal of Zoology 1992, 70:37-42.

26. Mylonas CC, Woods LC 3rd, Thomas P, Zohar Y: Endocrine profiles of female striped bass (Morone saxatilis) in captivity, during postvitellogenesis and induction of final oocyte maturation via controlled-release GnRHa-delivery systems. Gen Comp Endocrinol 1998, I I 0(3):276-289.

27. Zhu Y, Rice CD, Pang Y, Pace M, Thomas P: Cloning, expression, and characterization of a membrane progestin receptor and evidence it is an intermediary in meiotic maturation of fish oocytes. Proc Natl Acad Sci USA 2003, 100:223I-2236.

28. Patiño R, Thomas P: Effects of gonadotropin on ovarian intrafollicular processes during the development of oocyte maturational competence in a teleost, the Atlantic croaker: Evidence for two distinct stages of gonadotropic control of final oocyte maturation. Biol Reprod 1990, 43:818-877.

29. Das S, Thomas P: Pesticides interfere with the nongenomic action of a progestogen on meiotic maturation by binding to its plasma membrane receptor on fish oocytes. Endocrinology 1999, 140:1953-1956.

30. Thomas P: Chemical interference with genomic and nongenomic action of steroids in fishes: role of receptor binding. Mar Environ Res 2000, 50:127-134.

31. Ghosh S, Thomas P: Antagonistic effects of xenobiotics on steroid-induced final maturation of Atlantic croaker oocytes in vitro. Mar Environ Res 1995, 39:159-163.

32. Thomas $P$, Das $S$ : Correlations between binding affinities of C2I steroids for the maturation-inducing steroid membrane receptor in spotted seatrout ovaries and their agonist and antagonist activities in an oocyte maturation bioassay. Biol Reprod 1997, 57:999-1007.
Publish with BioMed Central and every scientist can read your work free of charge

"BioMed Central will be the most significant development for disseminating the results of biomedical research in our lifetime. "

Sir Paul Nurse, Cancer Research UK

Your research papers will be:

- available free of charge to the entire biomedical community

- peer reviewed and published immediately upon acceptance

- cited in PubMed and archived on PubMed Central

- yours - you keep the copyright
BioMedcentral 